\title{
Carbon tetrachloride-induced hepatic injury through formation of oxidized diacylglycerol and activation of the PKC/NF- $\kappa$ B pathway
}

\author{
Kentaro Toriumi ${ }^{1}$, Yosuke Horikoshi ${ }^{1}$, R Yoshiyuki Osamura ${ }^{1}$, Yorihiro Yamamoto ${ }^{2}$, Naoya Nakamura ${ }^{1}$ and \\ Susumu Takekoshi ${ }^{1,3}$
}

Protein kinase $C(P K C)$ participates in signal transduction, and its overactivation is involved in various types of cell injury. PKC depends on diacylglycerol (DAG) for its activation in vivo We have previously reported that DAG peroxides (DAG$\mathrm{O}(\mathrm{O}) \mathrm{H})$ activate $\mathrm{PKC}$ in vitro more strongly than unoxidized $\mathrm{DAG}$, suggesting that $\mathrm{DAG}-\mathrm{O}(\mathrm{O}) \mathrm{H}$, if generated in vivo under oxidative stress, would act as an aberrant signal transducer. The present study examined whether DAG-O(O)H are formed in carbon tetrachloride $\left(\mathrm{CCl}_{4}\right)$-induced acute rat liver injury in association with activation of the $\mathrm{PKC} /$ nuclear factor (NF)- $\kappa \mathrm{B}$ pathway. A single subcutaneous injection of $\mathrm{CCl}_{4}$ resulted in a marked increase in hepatic DAG-O(O)H content. At the molecular level, immunohistochemistry and subcellular fractionation combined with immunoblotting localized PKC $\alpha, \beta$, $\beta \mathrm{II}$ and $\delta$ isoforms to cell membranes, while immunoblotting showed phosphorylation of the p65 subunit of NF- $\kappa \mathrm{B}$, and immunoprecipitation using isoform-specific anti-PKC antibodies revealed specific association of PKC $\alpha$ and p65. In addition, expression of tumor necrosis factor $\alpha$ (TNF $\alpha$ ) and neutrophil invasion increased in the $\mathrm{CCl}_{4}$-treated rats. Furthermore, we demonstrated that Vitamin $\mathrm{E}$, one of the most important natural antioxidants that suppresses peroxidation of membrane lipids, significantly inhibited the $\mathrm{CCl}_{4}$-induced increase in hepatic DAG-O(O)H content and TNF $\alpha$ expression as well as phosphorylation of PKC $\alpha$ and p65. These data demonstrate for the first time that DAG-O(O)H are generated in the process of $\mathrm{CCl}_{4}$-induced liver injury, resulting in activation of the PKC/NF- $\kappa$ B pathway and TNF $\alpha$-mediated aggravation of liver injury.

Laboratory Investigation (2013) 93, 218-229; doi:10.1038/labinvest.2012.145; published online 3 December 2012

KEYWORDS: hepatic injury; oxidative stress; oxidized diacylglycerol; protein kinase C

Protein kinase C (PKC) has crucial roles in transducing signals that regulate physiological cellular functions, such as cell proliferation, differentiation and apoptosis. ${ }^{1-3} \mathrm{PKC}$ is also involved in inflammation and cell injury. ${ }^{4-6}$ In response to various extracellular stimuli, PKC is activated and triggers the nuclear factor $(\mathrm{NF})-\kappa \mathrm{B}$ pathway. ${ }^{7-9}$ Select roles of PKC isoforms have been suggested to be involved in alterations of cellular functions as well as activation of the $\mathrm{NF}-\kappa \mathrm{B}$ pathway. PKC is activated in oxidative stress-related diseases, such as cancer, cerebral ischemia-reperfusion injury and hepatic damage. ${ }^{10-12}$ However, the mechanism by which oxidative stress causes the activation of PKC remains unknown.
PKC is activated endogenously by diacylglycerol (DAG) and phosphatidylserine and exogenously by phorbol esters and oxidative stress. ${ }^{13-15}$ We have previously reported that DAG peroxides $(\mathrm{DAG}-\mathrm{O}(\mathrm{O}) \mathrm{H})$, which are peroxidation products of DAG, can activate crude rat brain PKC preparations more strongly than unoxidized DAG. ${ }^{16}$ We have also revealed that $\mathrm{DAG}-\mathrm{O}(\mathrm{O}) \mathrm{H}$ induced superoxide production by human peripheral neutrophils via phosphorylation p47 phox. ${ }^{17,18}$ In addition, we have demonstrated that UV irradiation-induced oxidative stress can promote the formation of $\mathrm{DAG}-\mathrm{O}(\mathrm{O}) \mathrm{H}$ in the mouse skin. ${ }^{19}$ Lipid peroxidation occurs in vitro as well as in vivo in the presence of reactive oxygen species, such as superoxide,

\footnotetext{
${ }^{1}$ Department of Pathology, Tokai University School of Medicine, Isehara, Kanagawa, Japan; ${ }^{2}$ School of Bioscience and Biotechnology, Tokyo University of Technology, Hachioji, Tokyo, Japan and ${ }^{3}$ Department of Cell Biology, Division of Host Defense Mechanism, Tokai University School of Medicine, Isehara, Kanagawa, Japan Correspondence: Dr S Takekoshi, Associate Professor, Department of Cell Biology, Division of Host Defense Mechanism, Tokai University School of Medicine, 143 Shimokasuya, Isehara, Kanagawa 259-1193, Japan.

E-mail: takekos@is.icc.u-tokai.ac.jp

Received 5 March 2012; revised 27 July 2012; accepted 15 August 2012
} 
hydroxyl radicals and hydrogen peroxide. ${ }^{20}$ Oxidative stress resulting from the accumulation of reactive oxygen species has been suggested in cell-signaling alterations. ${ }^{21}$ Our previous findings, therefore, indicate that $\mathrm{DAG}-\mathrm{O}(\mathrm{O}) \mathrm{H}$ may be generated in vivo under oxidative stress and activates PKC excessively.

Carbon tetrachloride $\left(\mathrm{CCl}_{4}\right)$ is a well-known hepatotoxin widely used to induce acute toxic liver injury in a wide range of laboratory animals. ${ }^{22} \mathrm{CCl}_{4}$ induces oxidative damage, inflammation, fatty degeneration and fibrosis in the liver. ${ }^{23-25}$ $\mathrm{NF}-\kappa \mathrm{B}$ is activated in the liver after $\mathrm{CCl}_{4}$ administration and is believed to have a major role in long-term $\mathrm{CCl}_{4}$ administration-induced chronic liver injury and fibrosis. ${ }^{26,27}$

In the present study, we examined whether DAG-O $(\mathrm{O}) \mathrm{H}$ are formed in the rat liver in $\mathrm{CCl}_{4}$-induced acute hepatic injury and activate the PKC/NF- $\kappa \mathrm{B}$ pathway.

\section{MATERIALS AND METHODS Experimental Model}

Male Wistar rats $(300 \mathrm{~g})$ were injected subcutaneously with an acute hepatotoxic dose of $\mathrm{CCl}_{4}(1.5 \mathrm{ml} / \mathrm{kg}$ body weight, Sigma-Aldrich, Dorset, UK). Rats receiving a corn oil alone were used as controls. Animals were humanely killed at 2, 6, 24, 48 or $72 \mathrm{~h}$ following $\mathrm{CCl}_{4}$ administration. In some experiments, Vitamin E (DL- $\alpha$-tocopherol acetate, $100 \mathrm{mg} / \mathrm{kg}$ body weight, Sigma-Aldrich) was intraperitoneally administered $24 \mathrm{~h}$ before $\mathrm{CCl}_{4}$ administration and animals were killed $6 \mathrm{~h}$ after $\mathrm{CCl}_{4}$ administration. The livers were removed from rats under anesthesia and weighed, snap-frozen in liquid nitrogen and kept at $-80^{\circ} \mathrm{C}$. A portion of the liver was immediately fixed in formalin for histological analyses. Plasma was analyzed for aspartate transaminase activity (SRL, Tokyo, Japan). All animal experiments were approved by the Animal Experimentation Committee, Isehara campus (Tokai University, Kanagawa, Japan).

\section{Immunohistochemistry}

A portion of liver tissue was fixed by immersion in Mildform $10 \mathrm{~N}$ (Wako, Osaka, Japan) overnight. In all, $4 \mu \mathrm{m}$ paraffinembedded sections were deparaffinized in xylene and rehydrated in graded series of ethanol. Endogenous peroxidase activity was blocked with $0.3 \%$ hydrogen peroxide in methanol for $30 \mathrm{~min}$. For immunostaining of phosphorylated p65 and 4-hydroxy-2-nonenal (HNE), the sections were boiled for $10 \mathrm{~min}$ at $98^{\circ} \mathrm{C}$ in $10 \mathrm{~mm}$ sodium citrate ( $\mathrm{pH}$ 6.0) to facilitate antigen retrieval. After treatment with $1 \%$ normal goat serum blocking buffer for $10 \mathrm{~min}$, the sections were incubated with the primary antibodies, rabbit immunoglobulin G (IgG) against phosphorylated p65 (1:20; Cell Signaling, Beverly, MA, USA) and mouse IgG against HNE (1:20; JAICA, Shizuoka, Japan), overnight at $4{ }^{\circ} \mathrm{C}$. Normal IgG (DAKO, Carpinteria, CA, USA) was used as negative control. For PKC and myeloperoxidase staining, the sections were first autoclaved at $121^{\circ} \mathrm{C}$ for $10 \mathrm{~min}$ in $10 \mathrm{~mm}$ sodium citrate $(\mathrm{pH} 8.0)$, and after treatment with $10 \%$ normal goat serum blocking buffer for $10 \mathrm{~min}$, the sections were incubated with the primary antibodies, rabbit IgG against $\mathrm{PKC} \alpha, \beta \mathrm{I}, \beta \mathrm{II}, \delta, \varepsilon$ or $\zeta(1: 100$; Santa Cruz Biotechnology, Santa Cruz, CA, USA) and myeloperoxidase (1:100; Meridian Life Science, Memphis, TN, USA), overnight at $4{ }^{\circ} \mathrm{C}$. Slides were then incubated with the secondary antibody using the Envision HRP Kit (DAKO) for 60 min at room temperature. Phosphorylated p65 staining was then incubated with the secondary antibody for $120 \mathrm{~min}$ at room temperature. For $\mathrm{TNF} \alpha$ staining, after blocking with $5 \%$ rabbit serum for $20 \mathrm{~min}$, the sections were incubated with goat anti-TNF $\alpha$ antibody (1:50; Santa Cruz) for $60 \mathrm{~min}$ at room temperature followed by incubation for $30 \mathrm{~min}$ with biotinylated anti-goat IgG (Vector Laboratories, Burlingame, CA, USA). The sections were subsequently incubated with avidin-biotin-peroxidase complex (Vector Laboratories) for $30 \mathrm{~min}$, staining was visualized with $3,3^{\prime}$-diaminobenzidine and nuclei were then counterstained with hematoxylin.

\section{Assay for Oxidized DAGs (DAG-O(O)H)}

Assay for DAG-O $(\mathrm{O}) \mathrm{H}$ was performed as described. ${ }^{19}$ Lipids were extracted from liver tissues with 2-propanol containing 1-palmitoyl-3-arachidoylglycerol hydroxide as an internal standard, $20 \mathrm{~mm}$ butylated hydroxytoluene and $200 \mathrm{~mm}$ triphenylphosphine. Butylated hydroxytoluene and triphenylphosphine were added to prevent artifactual oxidation during the analytical procedure and to reduce hydroperoxide to hydroxide, respectively. The extract was injected into an octadecylsilyl column, and the fraction containing DAG$\mathrm{O}(\mathrm{O}) \mathrm{H}$ was collected. Methanol was used as a mobile phase. Next, the fraction was injected into a silica column and, using hexane/2-propanol as a mobile phase, the fraction containing $\mathrm{DAG}-\mathrm{O}(\mathrm{O}) \mathrm{H}$ was collected. Then, $\mathrm{DAG}-\mathrm{O}(\mathrm{O}) \mathrm{H}$ were labeled with pyrene-1-carbonyl cyanide in the presence of quinuclidine, and the labeled DAG-O $(\mathrm{O}) \mathrm{H}$ were detected by reversed phase HPLC coupled with fluorescence detection (excitation at $330 \mathrm{~nm}$ and emission at $405 \mathrm{~nm}$ ). Various DAG-O $(\mathrm{O}) \mathrm{H}$ species with different acyl chains were eluted between 35 and $43 \mathrm{~min}$.

\section{Subcellular Fractionation}

Subcellular fractionation was performed as described with modifications. ${ }^{28}$ Frozen rat liver was homogenized by a Potter homogenizer in $5 \mathrm{ml}$ ice-cold homogenization buffer consisting of $25 \mathrm{~mm}$ Tris-HCI (pH 7.4), supplemented with protease inhibitor cocktail (Sigma). The homogenate was first centrifuged at $500 \mathrm{~g}$ for $5 \mathrm{~min}$ at $4{ }^{\circ} \mathrm{C}$ to remove tissue debris, then at $100,000 \mathrm{~g}$ for $60 \mathrm{~min}$ at $4^{\circ} \mathrm{C}$. The resultant supernatant containing cytosolic PKC was removed and stored at $-80^{\circ} \mathrm{C}$. The pellets were resuspended in $1 \mathrm{ml}$ of the above homogenized buffer containing 1\% Triton X-100, and membrane-associated PKC was extracted from the pellets by $5 \mathrm{~min}$ of vigorous intermittent vortexing for a total of $30 \mathrm{~min}$ on ice. The extract was centrifuged at $100,000 \mathrm{~g}$ for $60 \mathrm{~min}$, 
and the supernatant containing membrane-associated PKC was stored at $-80^{\circ} \mathrm{C}$.

\section{Immunoprecipitation}

Rat livers were homogenized on ice in lysis buffer consisting of $50 \mathrm{~mm}$ Tris- $\mathrm{HCl} \mathrm{pH} 8.0,150 \mathrm{~mm} \mathrm{HCl}, 1 \mathrm{~mm}$ EDTA, $1 \%$ Nonidet P-40, $10 \%$ glycerol, $50 \mathrm{~mm} \mathrm{NaF}$ and $10 \mathrm{~mm}$ sodium pyrophosphate. The lysate was then rotated at $4{ }^{\circ} \mathrm{C}$ for $1 \mathrm{~h}$ followed by centrifugation at $12,000 \mathrm{~g}$ for $20 \mathrm{~min}$. The supernatants were combined with $50 \mu \mathrm{l}$ of protein A sepharose beads (GE Healthcare, Bucks, UK) that had been preincubated with anti-PKC $\alpha, \beta \mathrm{I}, \beta \mathrm{II}, \delta$, $\varepsilon$, or $\zeta$ antibody (Santa Cruz) and incubated at $4{ }^{\circ} \mathrm{C}$ for $90 \mathrm{~min}$. The protein A sepharose beads were spun down and washed thoroughly three times using lysis buffer. The precipitates were resolved on SDS-PAGE gel and subjected to immunoblotting.

\section{Immunoblotting}

The protein concentration of each sample was measured using a DC protein assay kit (Bio-Rad, Hercules, CA, USA). The samples were heated at $95^{\circ} \mathrm{C}$ for $5 \mathrm{~min}$ and applied to $10 \%$ SDS-PAGE gels, and then separated proteins were transferred to nitrocellulose membranes (Millipore, Billerica, MA, USA). After blocking for $60 \mathrm{~min}$ at room temperature with $5 \%$ skim milk in phosphate-buffered saline containing $0.05 \%$ Tween 20, the membranes were incubated overnight at $4{ }^{\circ} \mathrm{C}$ with rabbit antibodies against $\mathrm{PKC} \alpha, \beta \mathrm{I}, \beta \mathrm{II}, \delta \varepsilon$, or $\zeta$ (1:800; Santa Cruz), total p65, or phosphorylated p65 (both 1:1000; Cell Signaling) or goat antibodies against TNF $\alpha$ (1:800; Santa Cruz) followed by incubation with peroxidaseconjugated anti-rabbit IgG antibody (Cell Signaling) or antigoat IgG antibody (GE Healthcare), respectively, at room temperature. Immune complexes were visualized by an enhanced ECL detection kit (GE Healthcare).

\section{Statistical Analysis}

Values are expressed as means $\pm \mathrm{SD}$. Differences were analyzed by Student's $t$-test, and statistical significance was considered when $P<0.05$.

\section{RESULTS}

\section{$\mathrm{CCl}_{4}$-Induced Oxidative Hepatic Injury}

To verify hepatic injury, we examined plasma aspartate transaminase activity and histological changes of the liver following $\mathrm{CCl}_{4}$ administration. Plasma aspartate transaminase activity markedly increased in the $\mathrm{CCl}_{4}$-treated rats as compared with the control rats (Figure 1a). Histological examination of liver sections at $24 \mathrm{~h}$ following $\mathrm{CCl}_{4}$ administration revealed extensive fatty degeneration of hepatocytes in the centrilobular zone (Figure 1b). HNE is a major endproduct of peroxidation of membrane $n$ - 6 -polyunsaturated fatty acids and is considered a marker of lipid oxidation. ${ }^{29}$ To verify oxidative damage, we performed immunohistochemistry for $\mathrm{HNE}$ adducts. In the $\mathrm{CCl}_{4}$-treated rats, $\mathrm{HNE}$ adducts were detected in the centrilobular zone as early as $2 \mathrm{~h}$ after $\mathrm{CCl}_{4}$ administration, and their distribution expanded with time (Figures $1 \mathrm{c}-\mathrm{i}$ ).

\section{Quantitative Determination of DAG-O(O)H}

Pyrene-fluorescence label techniques were used to investigate the formation of $\mathrm{DAG}-\mathrm{O}(\mathrm{O}) \mathrm{H}$ in the $\mathrm{CCl}_{4}$-treated rats. HPLC analysis of liver homogenates showed that the hepatic DAG-O $(\mathrm{O}) \mathrm{H}$ content significantly increased with time in the $\mathrm{CCl}_{4}$-treated rats (Figure 2). It is noteworthy that this increase in the hepatic DAG-O $(\mathrm{O}) \mathrm{H}$ content was evident as early as $2 \mathrm{~h}$ after $\mathrm{CCl}_{4}$ administration.

\section{Subcellular Localization of PKC Isoforms}

Six $\mathrm{PKC}$ isoforms are expressed in the rat liver: $\mathrm{PKC} \alpha, \beta \mathrm{I}, \beta \mathrm{II}$, $\delta, \varepsilon$ and $\zeta .^{30}$ Immunohistochemistry with isoform-specific anti-PKC antibodies localized intense PKC $\alpha$ expression to the plasma membrane of hepatocytes around the centrilobular vein at 2 and $6 \mathrm{~h}$ following $\mathrm{CCl}_{4}$ administration (Figure $3 \mathrm{a}$ ). $\mathrm{PKC} \beta \mathrm{I}, \beta \mathrm{II}$ and $\delta$ were also localized to the membrane of hepatocytes at 2 and $6 \mathrm{~h}$, respectively. Neither PKC $\varepsilon$ nor PKC $\zeta$ had translocated to the plasma membrane up to $6 \mathrm{~h}$ following $\mathrm{CCl}_{4}$ administration. Moreover, the subcellular distribution of PKC isoforms was assessed using subcellular fractionation of liver homogenates. Translocation of $\mathrm{PKC} \alpha$, $\beta \mathrm{I}, \beta \mathrm{II}$ and $\delta$ to the membrane fraction was seen in the $\mathrm{CCl}_{4}{ }^{-}$ treated rats at 2 and $6 \mathrm{~h}$ (Figure $3 \mathrm{~b}$ ). These data were consistent with the immunohistochemical observations. This finding suggests that DAG-O $(\mathrm{O}) \mathrm{H}$ formed under oxidative stress induced PKC activation.

\section{Phosphorylation of NF-kB p65 in the Liver of $\mathrm{CCl}_{4}^{-}$ Treated Rats}

Immunoblotting was used to examine the phosphorylation status of the p65 subunit of NF- $\kappa$ B. Phosphorylated p 65 was detected $2 \mathrm{~h}$ after $\mathrm{CCl}_{4}$ administration and increased with time (Figure 4a). Further, it was localized to the nuclei of hepatocytes around the central vein $2 \mathrm{~h}$ after $\mathrm{CCl}_{4}$ administration (Figures $4 \mathrm{~b}$ and $\mathrm{c}$ ).

To further determine which PKC isoform phosphorylated $\mathrm{p} 65$, immunoprecipitation was performed using anti-PKC $\alpha$, $\beta \mathrm{I}, \beta \mathrm{II}, \delta, \varepsilon$, or $\zeta$ antibody, and the precipitates were analyzed by immunoblotting. As shown in Figure 5, PKC $\alpha$, but not other PKC isoforms, was co-immunoprecipitated with the total p65 from liver homogenates of the $\mathrm{CCl}_{4}$-treated rats. Interestingly, $\mathrm{PKC} \alpha$ was also co-immunoprecipitated with phosphorylated $\mathrm{p} 65$. These data suggest that phosphorylation of NF- $\kappa \mathrm{B}$ p 65 is induced by the PKC $\alpha$ isoform in the liver of $\mathrm{CCl}_{4}$-treated rats.

\section{TNF $\alpha$ Expression and Neutrophil Invasion in the Liver of $\mathrm{CCl}_{4}$-Treated Rats}

We used immunohistochemistry and immunoblotting to examine the expression of $\mathrm{TNF} \alpha$, one of the targets of NF- $\kappa \mathrm{B}$. TNF $\alpha$ was intensely expressed 2 and $6 \mathrm{~h}$ after $\mathrm{CCl}_{4}$ administration in the cytoplasm of hepatocytes around the 

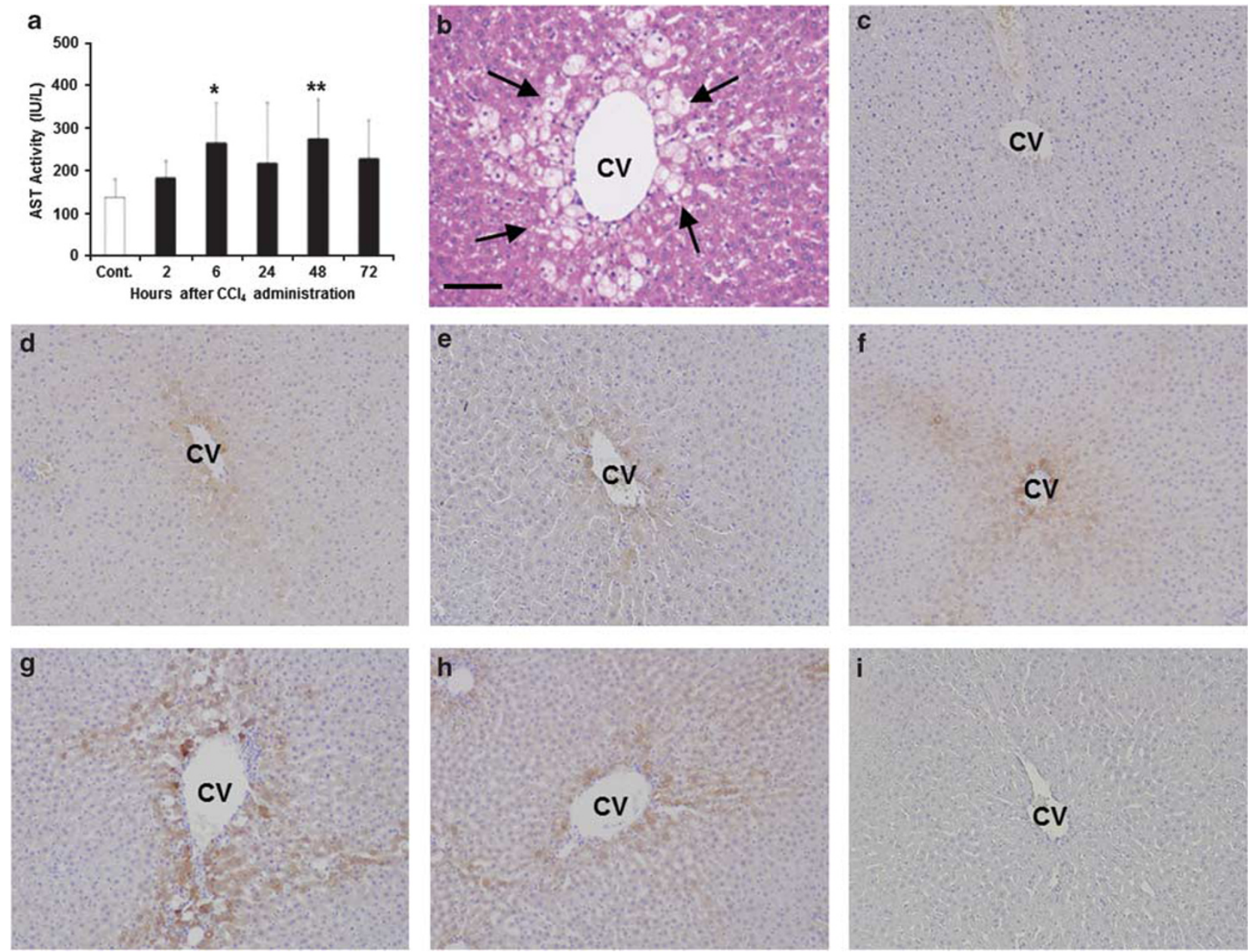

Figure 1 Oxidative liver injury following carbon tetrachloride $\left(\mathrm{CCl}_{4}\right)$ administration. (a) Plasma aspartate transaminase (AST) activity. Rats were administered vehicle (Cont.) or an acute hepatotoxic dose of $\mathrm{CCl}_{4}(1.5 \mathrm{ml} / \mathrm{kg}$ body weight), and plasma was collected 2, 6, 24, 48 and $72 \mathrm{~h}$. Each bar represents the mean \pm SD for six rats. ${ }^{*} P<0.05$ vs control, and ${ }^{*} P<0.01$ vs control by Student's $t$-test. (b) Hematoxylin and eosin staining of liver sections around the centrilobular vein (CV) at $24 \mathrm{~h}$ following $\mathrm{CCl}_{4}$ administration (Bar $=150 \mu \mathrm{m}$ ). Arrows indicate fatty degeneration of hepatocytes. (c-h) Immunohistochemical localization of 4-hydroxy-2-nonenal (HNE) adducts. Liver sections from (c) vehicle-administered control and (d-h) $\mathrm{CCl}_{4-}$ treated rats were harvested (d) $2 \mathrm{~h},(\mathbf{e}) 6 \mathrm{~h},(\mathbf{f}) 24 \mathrm{~h},(\mathbf{g}) 48 \mathrm{~h}$ and (h) $72 \mathrm{~h}$ following $\mathrm{CCl}_{4}$ administration and stained using anti-HNE antibody. (i) Staining control using non-immune mouse lgG.

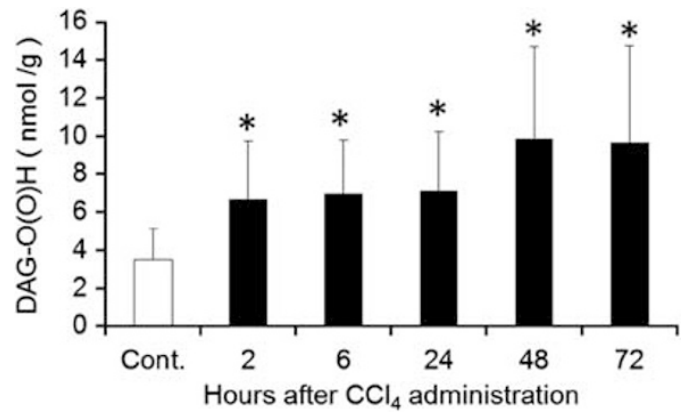

Figure 2 Hepatic diacylglycerol peroxides (DAG-O(O)H) content in carbon tetrachloride $\left(\mathrm{CCl}_{4}\right)$-induced acute liver injury. Livers from vehicle-administered (Cont.) and $\mathrm{CCl}_{4}$-treated rats were harvested 2, $6,24,48$ and $72 \mathrm{~h}$ after $\mathrm{CCl}_{4}$ administration, and DAG-O(O)H content was determined as described in Materials and Methods. Each bar represents the mean \pm SD for six rats. ${ }^{*} P<0.05$ vs control by Student's $t$-test. centrilobular vein, but the expression decreased by $24 \mathrm{~h}$ (Figure 6). Moreover, we observed immunolocalization of myeloperoxidase, a marker of neutrophils, in the centrilovular zone of the $\mathrm{CCl}_{4}$-treated rats 2 and $6 \mathrm{~h}$ after administration by immunohistochemistry and hematoxylin and eosinstaining (Figure 7). Our data suggest a role for lipid peroxidation-mediated DAG-O $(\mathrm{O}) \mathrm{H}$ formation in $\mathrm{CCl}_{4}{ }^{-}$ induced expression of cytokines and recruitment of inflammatory cells leading to hepatic injury.

\section{Effects of Vitamin E Administration on $\mathrm{CCl}_{4}$-Induced Alterations}

We administered Vitamin E, one of the most important natural antioxidants that suppress peroxidation of membrane lipids, $24 \mathrm{~h}$ before $\mathrm{CCl}_{4}$ injection, and all animals were killed 
a

PKCa

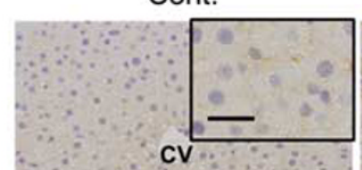

PKC $\beta \mid$

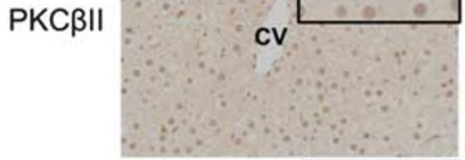

PKCס

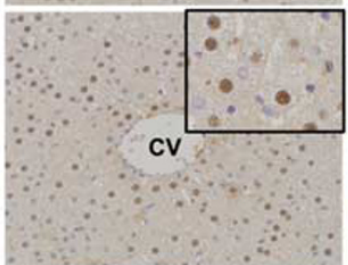

PKC $\varepsilon$

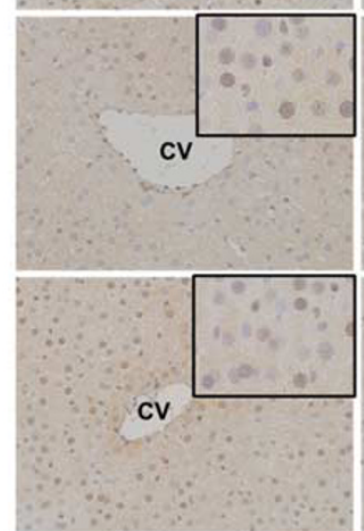

$2 \mathrm{hr}$

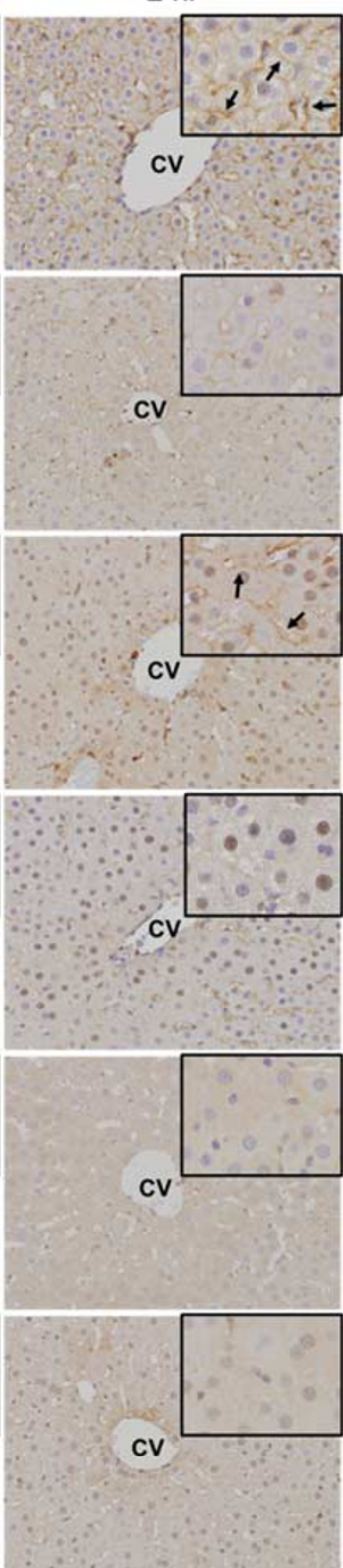

$6 \mathrm{hr}$

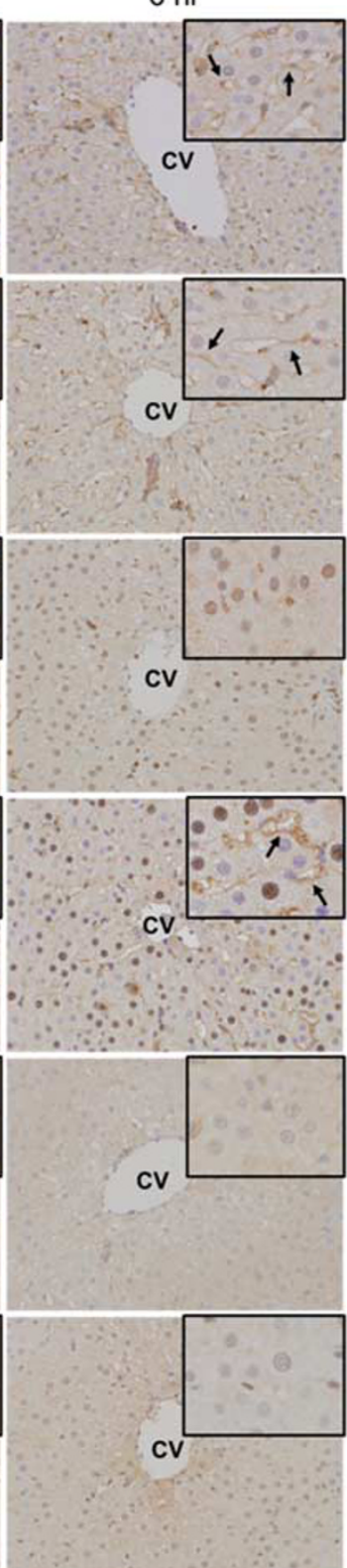

b

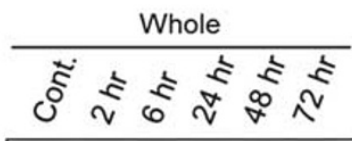

PKCa

PKC $\beta$ I $\square=$

РКС $\beta$ II

PKCठ

PKC $\varepsilon$

$\mathrm{PKC \zeta}$

$\beta$-Actin

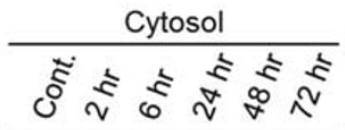

PKCa

PKC $\beta$ I

PKC $\beta$ II $=-\ldots$

PKCठ

PKCE

$\mathrm{PKC \zeta}$
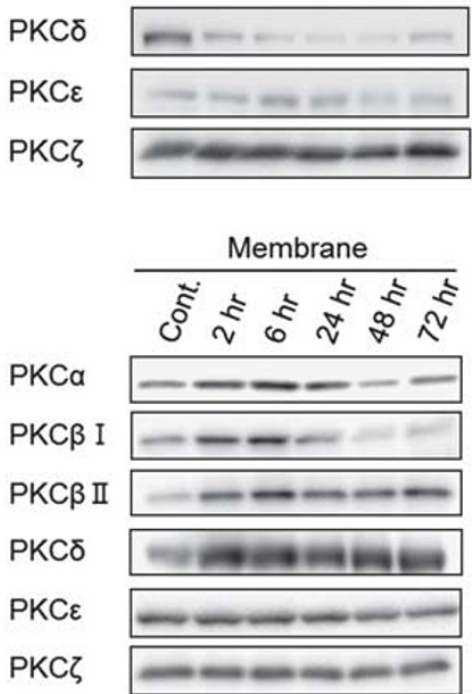

Figure 3 Immunohistochemical localization of protein kinase C (PKC) isoforms in carbon tetrachloride $\left(\mathrm{CCl}_{4}\right)$-induced acute liver injury. (a) Liver sections from vehicle-administered (Cont.) and $\mathrm{CCl}_{4}$-treated rats harvested 2 and $6 \mathrm{~h}$ after $\mathrm{CCl}_{4}$ administration were stained with isoform-specific anti-PKC antibodies. Representative sections are presented $(\mathrm{Bar}=100 \mu \mathrm{m})$. Insets are enlarged views $(\mathrm{Bar}=30 \mu \mathrm{m})$. Arrow heads indicate concentrated localization of PKC in the plasma membrane. CV, centrilobular vein. (b) The livers from vehicle-administered (Cont.) and $\mathrm{CCl}_{4}$-treated rats harvested 2, 6 , 24, 48 and $72 \mathrm{~h}$ after administration were homogenized and fractionated into cytosolic and membrane fractions. Unfractionated homogenate (Whole), cytosolic (Cytosol) and membrane (Membrane) fractions were subjected to immunoblotting using isoform-specific anti-PKC antibodies.

$6 \mathrm{~h}$ after $\mathrm{CCl}_{4}$ administration. Vitamin $\mathrm{E}$ blocked $\mathrm{CCl}_{4}$-induced increases in plasma aspartate transaminase activity (Figure 8a), fatty degeneration and HNE adducts and preserved liver histology (Figure 8b). The preserved liver function and histology were associated with suppression of the increase in hepatic DAG-O(O)H content (Figure 8c). Immunoblotting using phosphorylated PKC $\alpha / \beta \mathrm{II}$ antibody showed that Vitamin E significantly diminished phosphorylation of $\mathrm{PKC} \alpha / \beta \mathrm{II}$ and $\mathrm{NF}-\kappa \mathrm{B}$ p65 (Figures $8 \mathrm{~d}$ and e).
Furthermore, Vitamin E significantly inhibited TNF $\alpha$ expression in the rat livers (Figure 8f). These data demonstrate that formation of DAG-O $(\mathrm{O}) \mathrm{H}$ is involved in inflammatory hepatic injury via the PKC-NF- $\kappa$ B pathway in $\mathrm{CCl}_{4}$-treated rat liver.

\section{DISCUSSION}

This study addressed the question of whether DAG-O $(\mathrm{O}) \mathrm{H}$ are formed in vivo under oxidative stress and are associated 

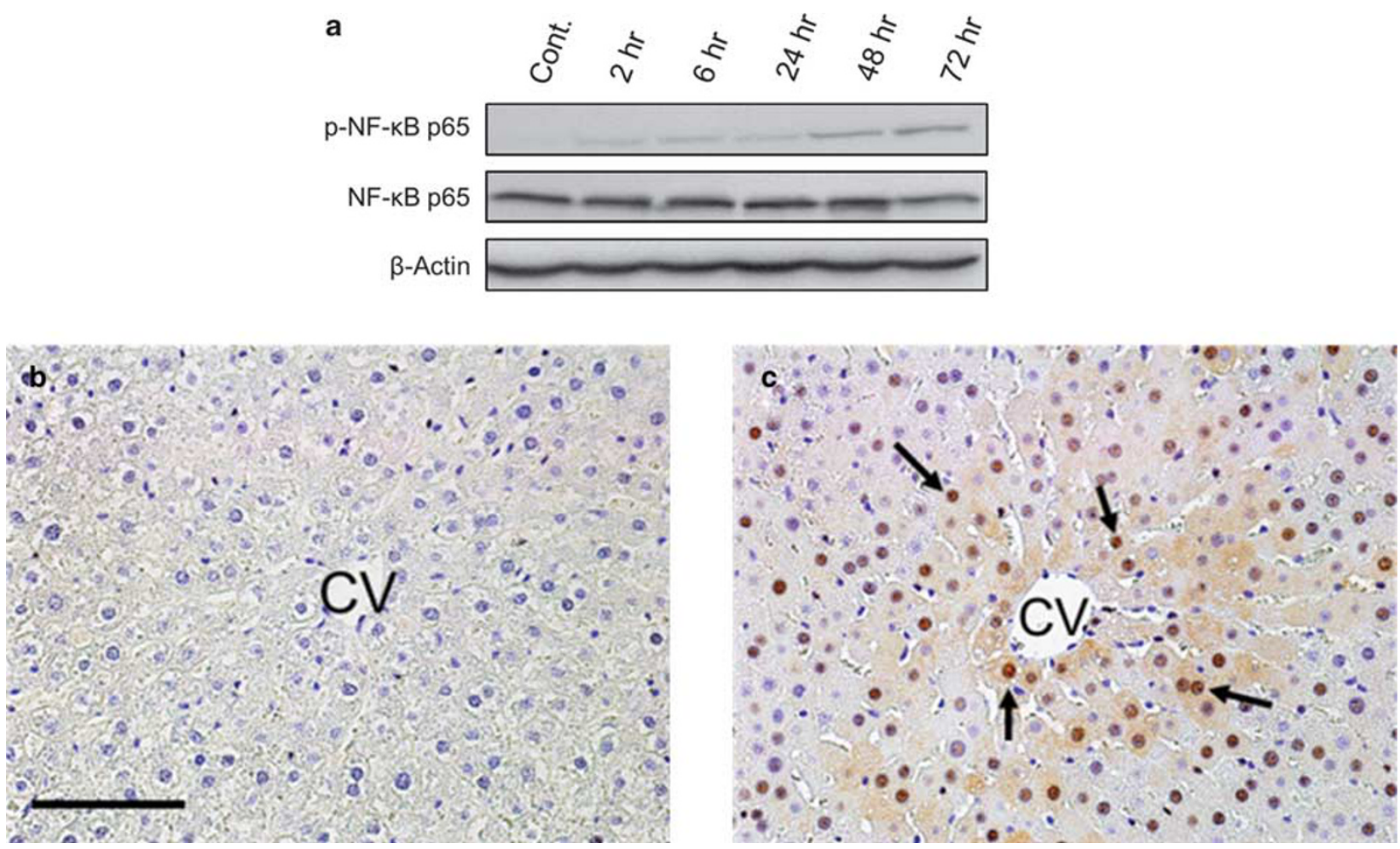

Figure 4 Phosphorylation of the nuclear factor (NF)- $\kappa$ B p65 subunit in carbon tetrachloride $\left(\mathrm{CCl}_{4}\right)$-induced acute liver injury. (a) The livers from vehicleadministered (Cont.) and $\mathrm{CCl}_{4}$-treated rats harvested 2, 6, 24, 48 and $72 \mathrm{~h}$ after administration were homogenized and subjected to immunoblotting using antibodies against phosphorylated or non-phosphorylated form of $\mathrm{p} 65$ subunit of NF- $\kappa \mathrm{B}$. The $\beta$-actin bands were used to correct for protein loading. (b and c) Immunohistochemical localization of phosphorylated NF- $\kappa$ B p 65 subunit. The livers from (b) vehicle-administered and (c) $\mathrm{CCl}_{4}$-treated rats harvested $2 \mathrm{~h}$ after administration were stained for phosphorylated NF- $\kappa \mathrm{B}$ p65 subunit. Arrows indicate intranuclear localization of the phosphorylated NF- $\kappa$ B p65 subunit (Bar $=100 \mu \mathrm{m})$. CV, centrilobular vein.
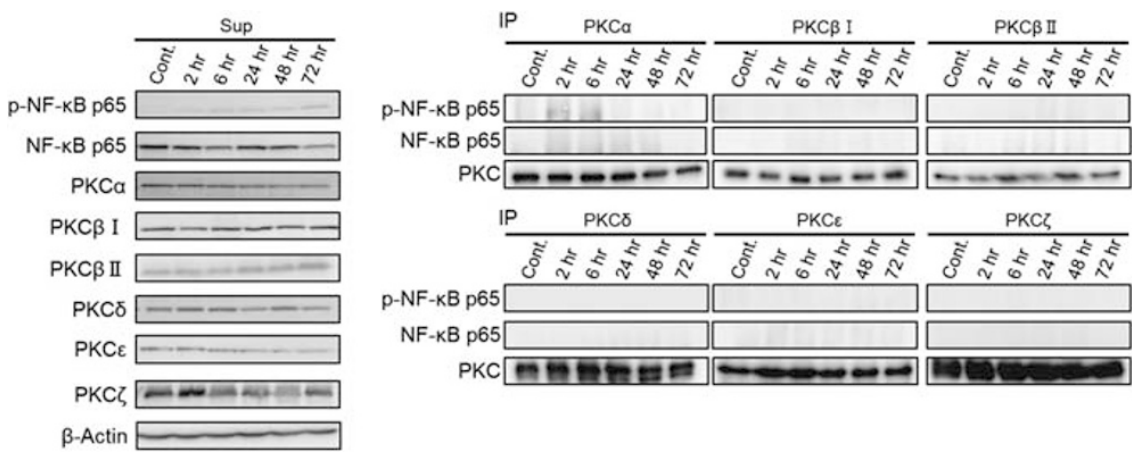

Figure 5 Physical association of protein kinase $\mathrm{C} \alpha(\mathrm{PKC} \alpha)$ and nuclear factor (NF)- $\kappa \mathrm{B}$ p65 subunit. The livers from vehicle-administered (Cont.) and carbon tetrachloride-treated rats harvested 2, 6, 24, 48 and $72 \mathrm{~h}$ after administration were homogenized and subjected to immunoprecipitation using isoform-specific anti-PKC antibodies. Left panel, the supernatant fraction (Sup) were analyzed by immunoblotting with antibodies against phosphorylated (p-NF- $\kappa$ B p65), non-phosphorylated NF- $\kappa$ B p65 subunit (NF- $\kappa$ B p65) or PKC isoforms. The $\beta$-actin bands were used to correct for protein loading. Right panels, the liver homogenates were immunoprecipitated (IP) with antibodies against PKC isoforms, and the precipitates were analyzed by immunoblotting using phosphorylated (p-NF- $\kappa$ B p65) or non-phosphorylated NF- $\kappa$ B p65 subunit (NF- $\kappa$ B p65) antibodies.

with progression of organ injury. For this purpose, we used a $\mathrm{CCl}_{4}$-induced rat model of acute liver injury characterized by increased oxidative stress. ${ }^{31}$ Our results showed that DAG$\mathrm{O}(\mathrm{O}) \mathrm{H}$ were formed in the liver upon $\mathrm{CCl}_{4}$ administration in parallel with accumulation of $\mathrm{HNE}$ adducts in the centrilobular zone. Interestingly, some but not all PKC isoforms were translocated to the plasma membrane, and the p65 subunit of the NF- $\kappa$ B complex was phosphorylated and physically associated with PKC $\alpha$. In addition, TNF $\alpha$ expression was increased at molecular levels. Furthermore, we demonstrated that administration of Vitamin E effectively inhibited the increases in hepatic DAG-O $(\mathrm{O}) \mathrm{H}$ content and TNF $\alpha$ expression as well as phosphorylation of PKC $\alpha$ and p65 and preserved liver histology. These findings demonstrated for the first time that $\mathrm{DAG}-\mathrm{O}(\mathrm{O}) \mathrm{H}$ were formed in vivo under oxidative stress and indicated that these 

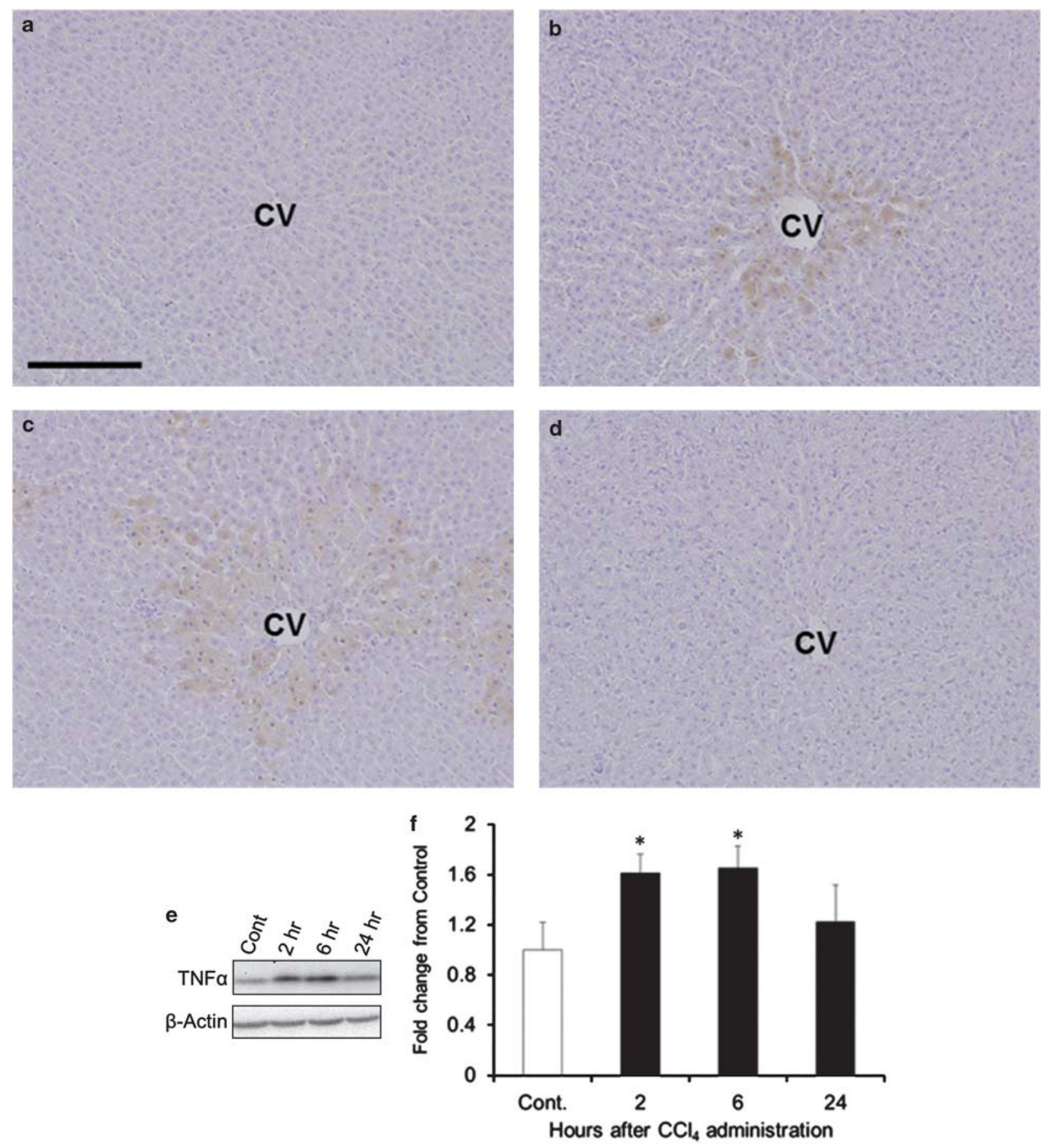

Figure 6 Increased tumor necrosis factor $\alpha(\mathrm{TNF} \alpha)$ expression in carbon tetrachloride $\left(\mathrm{CCl}_{4}\right)$-induced acute liver injury. (a-d) Immunohistochemical localization of TNF $\alpha$. Liver sections from (a) vehicle-administered and (b-d) $\mathrm{CCl}_{4}$-treated rats harvested at (b) $2 \mathrm{~h}$, (c) $6 \mathrm{~h}$ and (d) $24 \mathrm{~h}$ after administration were stained using anti-TNF $\alpha$ antibody. CV, centrilobular vein; (Bar $=200 \mu \mathrm{m})$. (e and $\mathbf{f})$ TNF $\alpha$ expression. TNF $\alpha$ levels were determined by immunoblotting in the livers from vehicle-administered (Cont.) and $\mathrm{CCl}_{4}$-treated rats harvested 2, 6 and $24 \mathrm{~h}$ after administration. The $\beta$-actin bands were used to correct for protein loading. Each bar represents the mean \pm SD for six rats. ${ }^{*} P<0.05$ vs control by Student's $t$-test.

molecules activated PKC, leading to the activation of the NF$\kappa \mathrm{B}$ pathway and increased production of inflammatory cytokines.

Upon $\mathrm{CCl}_{4}$ administration, $\mathrm{HNE}$ adducts, which are aldehyde byproducts of lipid peroxidation, were found to be increased in the centrilobular zone by immunohistochemistry as early as $2 \mathrm{~h}$ after treatment, thus indicating lipid peroxidation. ${ }^{32}$ Coinciding with the increase in HNE adducts, DAG-O(O)H increased in the liver $2 \mathrm{~h}$ after $\mathrm{CCl}_{4}$ administration. These findings indicate that this reagent 
caused lipid peroxidation primarily in the centrilobular zone, resulting in the generation of $\mathrm{DAG}-\mathrm{O}(\mathrm{O}) \mathrm{H}$.

Using immunohistochemistry and subcellular fractionation, we found that $\mathrm{PKC} \alpha, \beta \mathrm{I}, \beta \mathrm{II}$ and $\delta$ were translocated to the plasma membrane in the $\mathrm{CCl}_{4}$-treated rats. Membrane localization of $\mathrm{PKC} \alpha, \beta \mathrm{I}, \delta$ and $\varepsilon$ has been previously reported in cirrhotic livers of chronically $\mathrm{CCl}_{4}$-treated rats, ${ }^{30}$ but for $\mathrm{CCl}_{4}$-induced acute liver injury, the present study is the first to demonstrate selective activation of $\mathrm{PKC} \alpha, \beta \mathrm{I}, \beta \mathrm{II}$ and $\delta$ as evidenced by their membrane localization. PKC $\alpha, \beta$ I and $\beta \mathrm{II}$ are conventional $\mathrm{PKC}$ isoforms that require both DAG and $\mathrm{Ca}^{2+}$ ions for activation, while PKC $\delta$ and $\varepsilon$ are 'novel PKC' that need only DAG. ${ }^{33,34}$ Neither DAG nor $\mathrm{Ca}^{2+}$ ions are required for activation of atypical $\mathrm{PKC} \zeta .{ }^{35}$ Thus, the translocation of conventional $\mathrm{PKC} \alpha, \beta \mathrm{I}$ and $\beta \mathrm{II}$ and novel PKC $\delta$ isoforms observed in $\mathrm{CCl}_{4}$-induced acute liver injury suggests release of sequestered $\mathrm{Ca}^{2+}$ ions, implicating activation of phospholipase $\mathrm{C}$, findings which corroborate a previous study reporting that $\mathrm{CCl}_{4}$ administration is associated with PLC activation in rat liver. ${ }^{36}$ On the other hand, it has been shown that DAG-O $(\mathrm{O}) \mathrm{H}$ can activate brain PKC in vitro in the absence of $\mathrm{Ca}^{2+}$ ions. ${ }^{16}$ However, the possibility that DAG-O $(\mathrm{O}) \mathrm{H}$ alone can activate $\mathrm{PKC}$ in $\mathrm{CCl}_{4}$ induced acute liver injury is unlikely because PKC $\varepsilon$ was not translocated in our present study.

Immunoprecipitation with isoform-specific anti-PKC antibodies demonstrated physical association of NF- $\kappa \mathrm{B}$ p 65 with $\mathrm{PKC} \alpha$, but not with $\mathrm{PKC} \beta \mathrm{I}, \beta \mathrm{II}$ or $\delta$. These data indicate that despite the activation of $\mathrm{PKC} \alpha, \beta \mathrm{I}, \beta \mathrm{II}$ and $\delta, \mathrm{PKC} \alpha$ alone mediates NF- $\kappa \mathrm{B}$ activation with direct molecular interaction in $\mathrm{CCl}_{4}$-induced acute liver injury, adding another example to selective $\mathrm{PKC} \alpha$ isoform involvement in NF- $\kappa \mathrm{B}$ activation. ${ }^{7,8}$ The observed co-immunoprecipitation of $\mathrm{PKC} \alpha$ with both phosphorylated and unphosphorylated forms of p65 suggest continuous, rather than transient, $\mathrm{PKC} \alpha$-mediated $\mathrm{NF}-\kappa \mathrm{B}$ activation. On the other hand, it has been noted that PKC $\delta$ activates NF- $\kappa \mathrm{B}$ in oxidative stress condition. Storz et al. ${ }^{37}$ have demonstrated that $\mathrm{PKC} \delta$ can activate NF- $\kappa \mathrm{B}$ through the
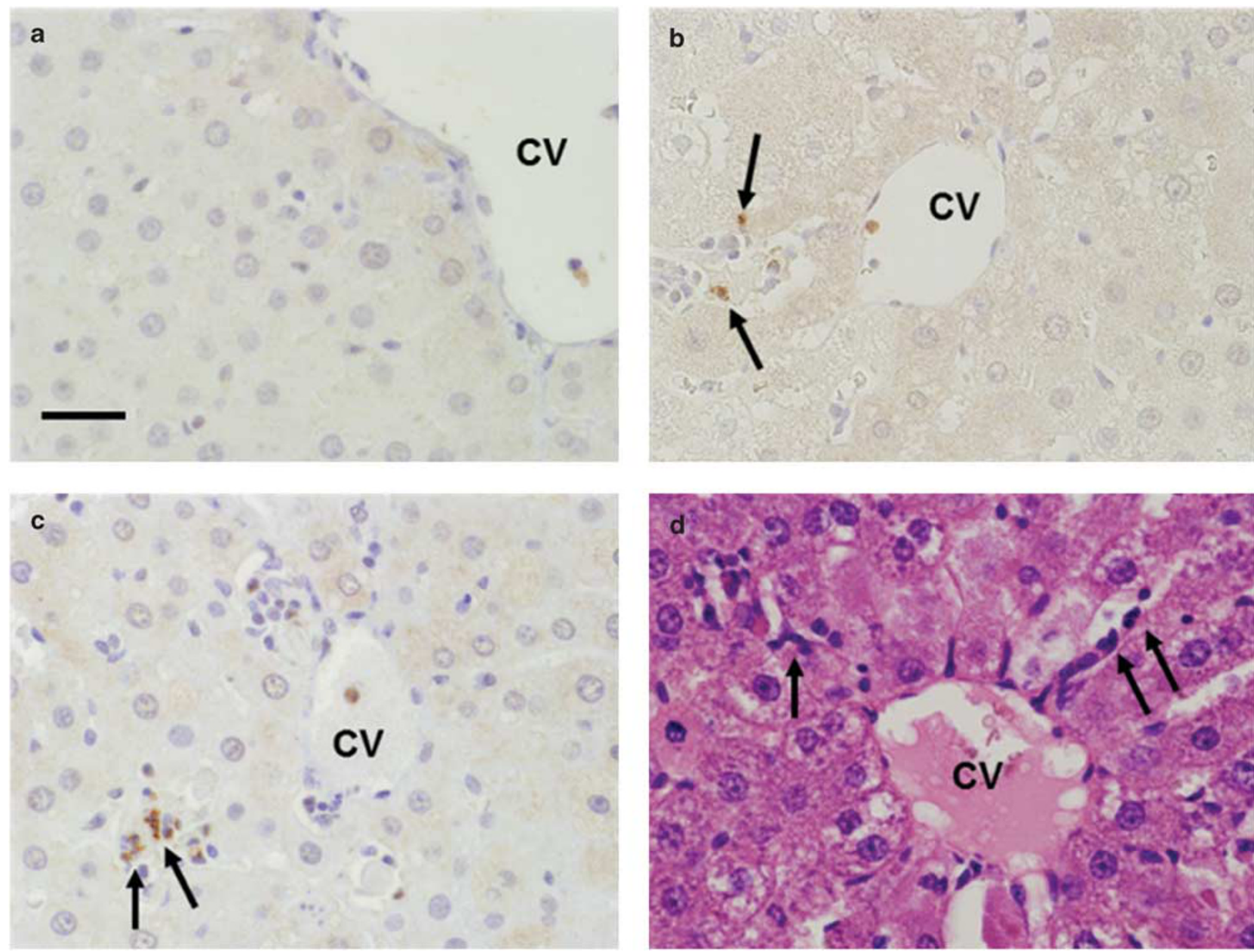

Figure 7 Neutrophil invasion in carbon tetrachloride $\left(\mathrm{CCl}_{4}\right)$-induced acute liver injury. (a-c) Immunohistochemical localization of myeloperoxidase, marker of neutrophils. Liver sections from (a) vehicle-administered and (b-d) $\mathrm{CCl}_{4}$-treated rats harvested at (b) $2 \mathrm{~h}$ and (c) $6 \mathrm{~h}$ after administration were stained using anti-myeloperoxidase antibody $(\mathrm{Bar}=30 \mu \mathrm{m})$. (d) Hematoxylin and eosin staining of liver sections around centrilobular vein $(\mathrm{CV})$ at $6 \mathrm{~h}$ following $\mathrm{CCl}_{4}$ administration. Arrows indicate neutrophils. 
phosphorylation of PKD catalytic kinase domain in cells exposed to oxidative stress. Furthermore, our results indicated that $\operatorname{PKC} \delta$ is also activated as well as $\operatorname{PKC} \alpha$ in
$\mathrm{CCl}_{4}$-treated rat liver. Accordingly, it is conceivable that $\mathrm{NF}-\kappa \mathrm{B}$ may be indirectly activated by an alternative $\mathrm{PKC} \delta$ signaling pathway.
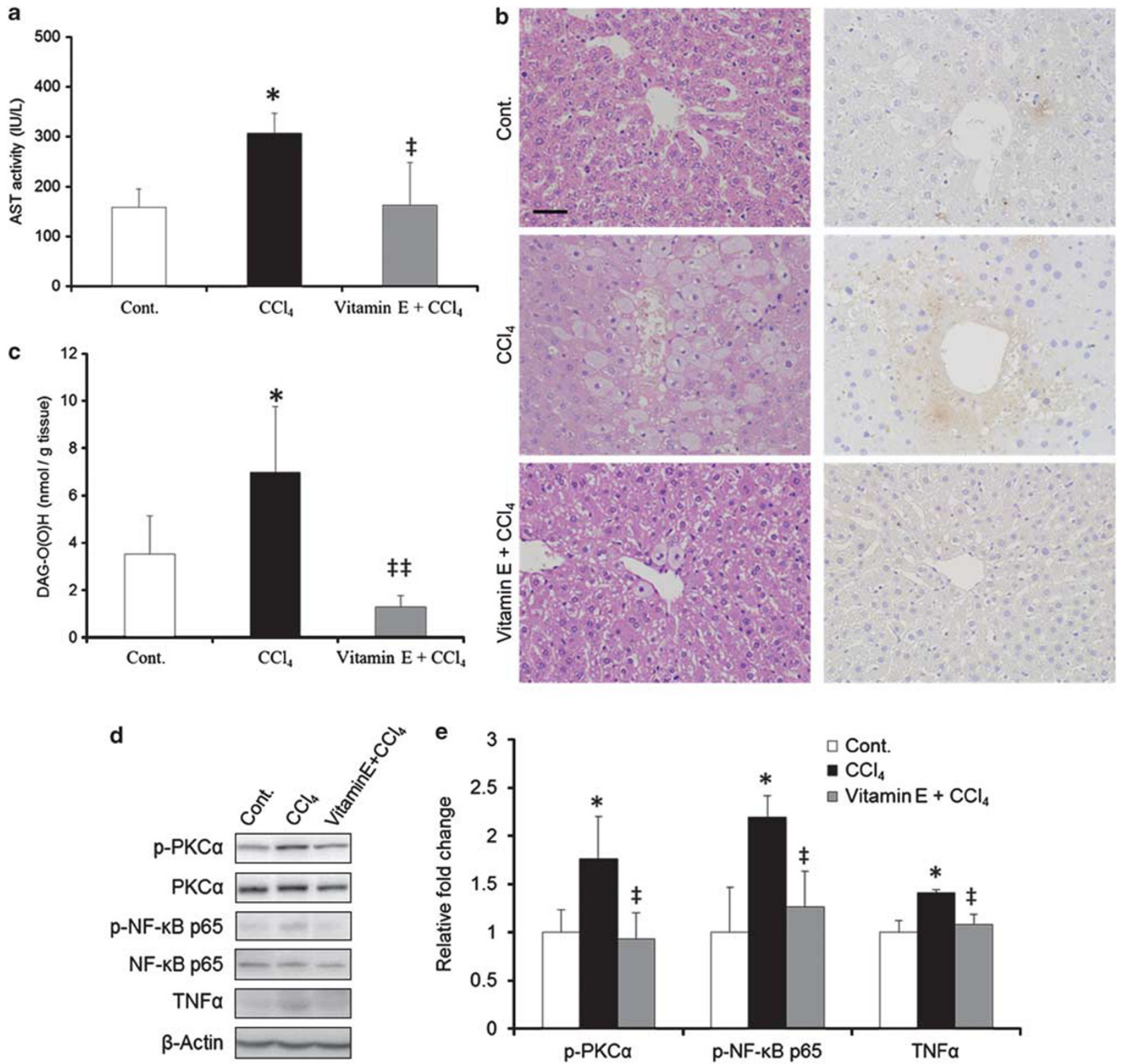

f

Cont.

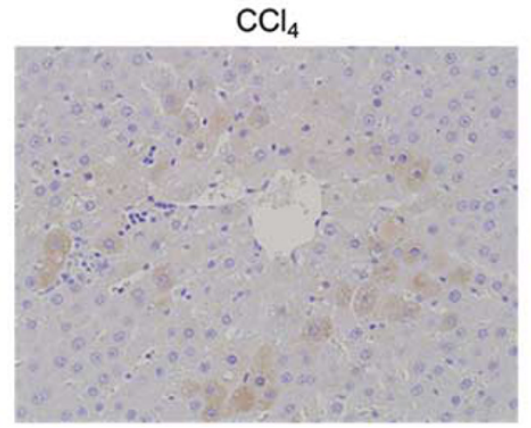

Vitamin $\mathrm{E}+\mathrm{CCl}_{4}$
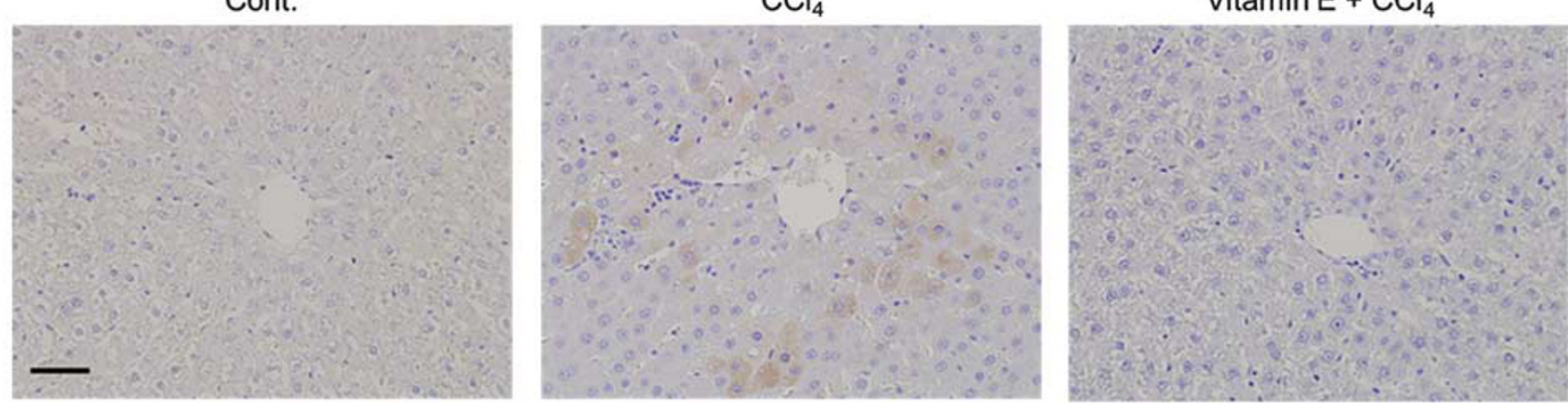
Immunohistochemistry and immunoblotting demonstrated increased expression of $\mathrm{TNF} \alpha$, a target of transcriptional activation by NF- $\kappa \mathrm{B}$, further underlining activation of $\mathrm{NF}-\kappa \mathrm{B}$ in $\mathrm{CCl}_{4}$-induced acute liver injury. ${ }^{26,38,39}$ Several reports have pointed out the importance of inflammation in $\mathrm{CCl}_{4}$-induced hepatic injury. ${ }^{40} \mathrm{TNF} \alpha$ knockout mice showed decreased liver injury following $\mathrm{CCl}_{4}$ administration. ${ }^{41}$ On the other hand, decreased expression of TNF $\alpha$ at $24 \mathrm{~h}$ was not correlated with time-dependent accumulation of DAG$\mathrm{O}(\mathrm{O}) \mathrm{H}$. Previous reports also showed similar findings that expression of $\mathrm{TNF} \alpha$ increased in the livers of $\mathrm{CCl}_{4}$-treated rodents up to $12 \mathrm{~h}$ after reagent administration and decreased at $24 \mathrm{~h}$ after $\mathrm{CCl}_{4}$ administration. ${ }^{41}{ }^{42}$ Furthermore, expression of interleukin-10, which is involved in inhibition of TNFa expression is increased $24 \mathrm{~h}$ after $\mathrm{CCl}_{4}$ administration. ${ }^{43,44}$ Therefore, decreased expression of $\mathrm{TNF} \alpha$ at $24 \mathrm{~h}$ after $\mathrm{CCl}_{4}$

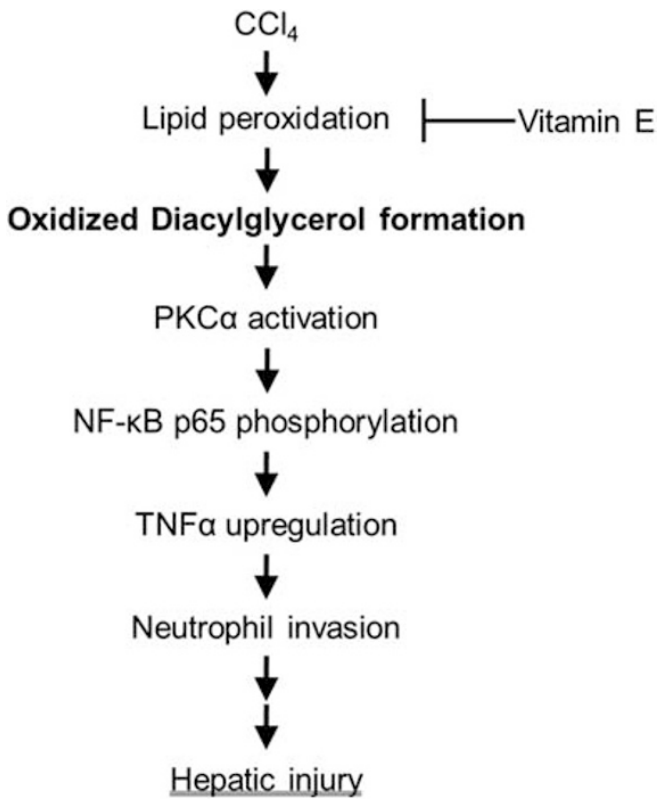

Figure 9 Proposed model of diacylglycerol peroxides (DAG-O(O)H)induced hepatic injury. DAG-O(O)H induce activation of protein kinase $\mathrm{C}$ $\alpha(\mathrm{PKC} \alpha)$ and nuclear factor (NF)- $\kappa \mathrm{B}$ p65 phosphorylation, which ultimately increases tumor necrosis factor $\alpha$ (TNF $\alpha$ ) expression and induces neutrophil invasion. Vitamin E effectively inhibits the formation of DAG-O(O)H content and PKC/NF- $\kappa$ B pathway, with amelioration of liver injury. $\mathrm{CCl}_{4}$, carbon tetrachloride. administration is considered to be through interleukin-10 signaling and independent from the PKC-NF- $\kappa$ B pathway.

We demonstrated that previous administration of Vitamin $\mathrm{E}$ effectively inhibited the formation of $\mathrm{DAG}-\mathrm{O}(\mathrm{O}) \mathrm{H}$ in vivo. However, membrane translocation of PKC could not be used to determine the consequence of Vitamin $\mathrm{E}$-induced inhibition of DAG-O $(\mathrm{O}) \mathrm{H}$ formation because it has been reported that Vitamin E directly promotes PKC translocation to plasma membranes, although without activating it, ${ }^{45,46}$ and our attempts indeed showed that Vitamin $\mathrm{E}$ also induced membrane translocation of PKC (data not shown). We therefore examined PKC $\alpha / \beta$ II autophosphorylation, the essential event for PKC activation, ${ }^{47}$ and found that $\mathrm{PKC} \alpha / \beta \mathrm{II}$ autophosphorylation was suppressed in Vitamin E-pretreated rat livers. We also revealed that Vitamin E suppressed phosphorylation of NF- $\kappa \mathrm{B}$ p65, $\mathrm{TNF} \alpha$ expression and liver injury. These findings indicate that $\mathrm{DAG}-\mathrm{O}(\mathrm{O}) \mathrm{H}$ formed upon $\mathrm{CCl}_{4}$ administration activate $\mathrm{PKC}$, leading to NF- $\kappa \mathrm{B}$ activation and $\mathrm{TNF} \alpha$ expression.

Long-term $\mathrm{CCl}_{4}$ administration is a potent inducer of liver fibrosis. ${ }^{48}$ It has recently been reported that PKC inhibitors attenuate fibrotic liver injury. ${ }^{49}$ In addition, ebselen, a glutathione peroxidase mimetic, has been found to suppress liver fibrosis in rats with $\mathrm{CCl}_{4}$-induced cirrhosis. ${ }^{50}$ We have also reported that ebselen or phospholipid hydroperoxide glutathione peroxidase (PHGPx) reduces DAG-O $(\mathrm{O}) \mathrm{H}$ to corresponding hydroxides, whereas the conventional cytosolic glutathione peroxidase does not. ${ }^{51} \mathrm{~A}$ recent report demonstrated that overexpression of PHGPX inhibited phosphatidylcholine hydroperoxide-mediated NF- $\kappa \mathrm{B}$ phosphorylation in UVA-irradiated human dermal fibroblasts. ${ }^{52}$ As UV irradiation-induced oxidative stress can induce the formation of DAG-O $(\mathrm{O}) \mathrm{H}$ in mouse skin, ${ }^{19}$ $\mathrm{NF}-\kappa \mathrm{B}$ phosphorylation in the above UV-irradiated human dermal fibroblasts may also involve DAG-O(O)H-mediated PKC activation. Long-Evans Cinnamon (LEC) rat is a mutant strain that displays hereditary hepatitis with elevation of copper levels and reactive oxygen species accompanied by severe jaundice at about 3-4 months after birth and develop hepatic cancer at about 1 year after birth. ${ }^{53}$ In LEC rats, hepatic DAG-O $(\mathrm{O}) \mathrm{H}$ levels markedly increased but not in trientine-treated rats, which is a strong copper chelator (data not shown). Consequently, it is conceivable that DAG$\mathrm{O}(\mathrm{O}) \mathrm{H}$ may participate in the occurrence of chronic liver

Figure 8 Inhibition of diacylglycerol peroxides (DAG-O(O)H) formation by Vitamin $\mathrm{E}$ is associated with amelioration of liver injury. (a) Plasma aspartate transaminase (AST) activity. Rats were administered vehicle (Cont.) or an acute hepatotoxic dose of carbon tetrachloride $\left(\mathrm{CCl}_{4}\right) 6 \mathrm{~h}$ after administration. A group of rats were intraperitoneally administered Vitamin E $24 \mathrm{~h}$ before $\mathrm{CCl}_{4}$ injection $\left(\right.$ Vitamin $\left.\mathrm{E}+\mathrm{CCl}_{4}\right)$. Each bar represents the mean $\pm \mathrm{SD}$ for four rats. ${ }^{*} P<0.05$ vs control, and ${ }^{\ddagger} P<0.05$ vs $\mathrm{CCl}_{4}$ by Student's $t$-test. (b) Hematoxylin and eosin staining (left panels) and immunohistochemistry for 4-hydroxy-2-nonenal (HNE) adducts (right panels) of liver sections around the centrilobular vein (CV; Bar = 50 $\mu \mathrm{m})$. (c) Hepatic DAG-O(O)H content. Each bar represents the mean \pm SD for six rats. ${ }^{*} P<0.05$ vs control, and ${ }^{\ddagger \ddagger} P<0.01$ vs $\mathrm{CCl}_{4}$ by Student's $t$-test. (d) Immunoblotting for protein kinase $C \alpha$ $(\mathrm{PKC} \alpha) / \beta \mathrm{ll}$, nuclear factor (NF)- $\kappa \mathrm{B}$ p65 and tumor necrosis factor $\alpha(\mathrm{TNF} \alpha)$ proteins. Liver homogenates were immunoblotted with antibody against phosphorylated PKC $\alpha / \beta \|$ I (p-PKC $\alpha$ ), non-phosphorylated PKC $\alpha$ (PKC $\alpha$ ), phosphorylated NF- $\kappa$ B p65 (p-NF- $\kappa$ B p65), non-phosphorylated NF- $\kappa$ B p65 (NF- $\kappa$ B p65) or TNF $\alpha$ proteins. The $\beta$-actin bands were used to correct for protein loading. (e) Densitometric analysis of the immunoblotting shown in (d). Each bar represents the mean \pm SD for three rats. ${ }^{*} P<0.05$ vs control, and ${ }^{\ddagger} P<0.05$ vs $\mathrm{CCl}_{4}$ by Student's $t$-test. (f) Immunohistochemical localization of TNF $\alpha$ in liver sections around the CV $(B a r=50 \mu \mathrm{m})$. 
disease arising from oxidative stress. We are currently working on this hypothesis.

Taken together, our study demonstrated that DAG-O $(\mathrm{O}) \mathrm{H}$ are formed in the liver of $\mathrm{CCl}_{4}$-treated rats and activate $\mathrm{PKC} \alpha, \beta \mathrm{I}, \beta \mathrm{II}$ and $\delta$ isoforms. We also showed that $\mathrm{PKC} \alpha$ activates the NF- $\kappa$ B pathway, leading to increased expression of inflammatory cytokines. Utilizing Vitamin E, we provided evidence that $\mathrm{DAG}-\mathrm{O}(\mathrm{O}) \mathrm{H}$ formed via lipid peroxidation activate $\mathrm{PKC} / \mathrm{NF}-\kappa \mathrm{B}$ pathway and contribute to the progression of liver injury (Figure 9). We speculate that oxidized DAG underlies aberrant PKC activation seen under oxidative stress.

\section{ACKNOWLEDGEMENTS}

We thank Takayuki Suzuki, Shotaro Tsuchiya and Hideyo Henzan (Tokai University School of Medicine) for technical support for the experiments; Hideaki Hasegawa, Yoshiko Itoh, Johbu Itoh, Katsuko Naito and Hideo Tsukamoto (Teaching and Research Support Center, Tokai University School of Medicine) for their technical support. This work was supported by a Tokai University School of Medicine Research Aid and by a Grant-in-Aid for Scientific Research (C) (no. 20590385) from the Japanese Society for the Promotion of Science.

\section{DISCLOSURE/CONFLICT OF INTEREST}

The authors declare no conflict of interest.

1. Rodriguez-Gallego C, Arnaiz-Villena A, Corell A, et al. Primary $T$ lymphocyte immunodeficiency associated with a selective impairment of CD2, CD3, CD43 (but not CD28)-mediated signal transduction. Clin Exp Immunol 1994;97:386-391.

2. Tonetti DA, Henning-Chubb C, Yamanishi DT, et al. Protein kinase C-beta is required for macrophage differentiation of human HL-60 leukemia cells. J Biol Chem 1994;269:23230-23235.

3. Majumder PK, Pandey P, Sun X, et al. Mitochondrial translocation of protein kinase $C$ delta in phorbol ester-induced cytochrome $c$ release and apoptosis. J Biol Chem 2000;275:21793-21796.

4. Kamo N, Shen XD, Ke B, et al. Sotrastaurin, a protein kinase $C$ inhibitor, ameliorates ischemia and reperfusion injury in rat orthotopic liver transplantation. Am J Transplant 2011;11:2499-2507.

5. Alchera E, Dal Ponte C, Imarisio C, et al. Molecular mechanisms of liver preconditioning. World J Gastroenterol 2010;16:6058-6067.

6. Mandil R, Ashkenazi E, Blass M, et al. Protein kinase Calpha and protein kinase Cdelta play opposite roles in the proliferation and apoptosis of glioma cells. Cancer Res 2001;61:4612-4619.

7. Ji Y, Liu J, Wang Z, et al. Angiotensin II induces inflammatory response partly via toll-like receptor 4-dependent signaling pathway in vascular smooth muscle cells. Cell Physiol Biochem 2009;23:265-276.

8. Asehnoune K, Strassheim D, Mitra S, et al. Involvement of PKC alpha/ beta in TLR4 and TLR2 dependent activation of NF-kappaB. Cell Signal 2005;17:385-394.

9. Koon HW, Zhao D, Zhan Y, et al. Substance P-stimulated interleukin-8 expression in human colonic epithelial cells involves protein kinase $C$ delta activation. J Pharmacol Exp Ther 2005;314:1393-1400.

10. Espinosa I, Briones J, Bordes R, et al. Membrane PKC-beta 2 protein expression predicts for poor response to chemotherapy and survival in patients with diffuse large B-cell lymphoma. Ann Hematol 2006; 85:597-603.

11. Bright $R$, Mochly-Rosen D. The role of protein kinase $C$ in cerebral ischemic and reperfusion injury. Stroke 2005;36:2781-2790.

12. Nitti M, Pronzato MA, Marinari UM, et al. PKC signaling in oxidative hepatic damage. Mol Aspects Med 2008;29:36-42.

13. Rosse $\mathrm{C}$, Linch $\mathrm{M}$, Kermorgant $\mathrm{S}$, et al. PKC and the control of localized signal dynamics. Nat Rev Mol Cell Biol 2010;11:103-112.

14. Shih SC, Mullen A, Abrams $K$, et al. Role of protein kinase $C$ isoforms in phorbol ester-induced vascular endothelial growth factor expression in human glioblastoma cells. J Biol Chem 1999:274: 15407-15414.

15. Whisler RL, Goyette MA, Grants IS, et al. Sublethal levels of oxidant stress stimulate multiple serine/threonine kinases and suppress protein phosphatases in Jurkat T cells. Arch Biochem Biophys 1995: 319:23-35.

16. Takekoshi $\mathrm{S}$, Kambayashi $\mathrm{Y}$, Nagata $\mathrm{H}$, et al. Activation of protein kinase $\mathrm{C}$ by oxidized diacylglycerols. Biochem Biophys Res Commun 1995;217:654-660.

17. Yamamoto $Y$, Kambayashi $Y$, Ito $T$, et al. 1,2-Diacylglycerol hydroperoxides induce the generation and release of superoxide anion from human polymorphonuclear leukocytes. FEBS Lett 1997;412:461-464.

18. Kambayashi $Y$, Takekoshi S, Tanino Y, et al. Various molecular species of diacylglycerol hydroperoxide activate human neutrophils via PKC activation. J Clin Biochem Nutr 2007;41:68-75.

19. Tanino Y, Budiyanto A, Ueda M, et al. Decrease of antioxidants and the formation of oxidized diacylglycerol in mouse skin caused by UV irradiation. J Dermatol Sci 2005S21-S28.

20. Yamamoto $\mathrm{Y}$, Brodsky $\mathrm{MH}$, Baker JC, et al. Detection and characterization of lipid hydroperoxides at picomole levels by highperformance liquid chromatography. Anal Biochem 1987;160:7-13.

21. Bartz RR, Piantadosi CA. Clinical review: oxygen as a signaling molecule. Crit Care 2010;14:234.

22. Bursch W, Taper HS, Somer MP, et al. Histochemical and biochemical studies on the effect of the prostacyclin derivative iloprost on $\mathrm{CCl}_{4-}$ induced lipid peroxidation in rat liver and its significance for hepatoprotection. Hepatology 1989;9:830-838.

23. Reyes-Gordillo K, Segovia J, Shibayama M, et al. Curcumin protects against acute liver damage in the rat by inhibiting NF-kappa B, proinflammatory cytokines production and oxidative stress. Biochim Biophys Acta 2007;1770:989-996.

24. Hattori S, Dhar DK, Hara N, et al. FR-167653, a selective p38 MAPK inhibitor, exerts salutary effect on liver cirrhosis through downregulation of Runx2. Lab Invest 2007;87:591-601.

25. Chen P, Li C, Pang W, et al. The protective role of Per2 against carbon tetrachloride-induced hepatotoxicity. Am J Pathol 2009;174:63-70.

26. Salazar-Montes A, Ruiz-Corro L, Sandoval-Rodriguez A, et al. Increased DNA binding activity of NF-kappaB, STAT-3, SMAD3 and AP-1 in acutely damaged liver. World J Gastroenterol 2006;12:5995-6001.

27. Son G, limuro Y, Seki E, et al. Selective inactivation of NF-kappaB in the liver using NF-kappaB decoy suppresses $\mathrm{CCl}_{4}$-induced liver injury and fibrosis. Am J Physiol Gastrointest Liver Physiol 2007;293:G631-G639.

28. Considine RV, Nyce MR, Allen LE, et al. Protein kinase $C$ is increased in the liver of humans and rats with non-insulin-dependent diabetes mellitus: an alteration not due to hyperglycemia. J Clin Invest 1995;95:2938-2944.

29. Kimoto T, Koya-Miyata S, Hino K, et al. Pulmonary carcinogenesis induced by ferric nitrilotriacetate in mice and protection from it by Brazilian propolis and artepillin C. Virchows Arch 2001;438:259-270.

30. Jeong $\mathrm{DH}$, Lee $\mathrm{SJ}$, Lee $\mathrm{JH}$, et al. Subcellular redistribution of protein kinase $\mathrm{C}$ isozymes is associated with rat liver cirrhotic changes induced by carbon tetrachloride or thioacetamide. J Gastroenterol Hepatol 2001;16:34-40.

31. Comporti M. Three models of free radical-induced cell injury. Chem Biol Interact 1989;72:1-56.

32. Catala A. Lipid peroxidation of membrane phospholipids generates hydroxy-alkenals and oxidized phospholipids active in physiological and/or pathological conditions. Chem Phys Lipids 2009;157:1-11.

33. Kishimoto A, Takai $Y$, Mori $T$, et al. Activation of calcium and phospholipid-dependent protein kinase by diacylglycerol, its possible relation to phosphatidylinositol turnover. J Biol Chem 1980;255:2273-2276.

34. Ono Y, Fujii T, Ogita K, et al. The structure, expression, and properties of additional members of the protein kinase C family. J Biol Chem 1988;263:6927-6932.

35. Ono Y, Fujii T, Ogita $K$, et al. Protein kinase $C$ zeta subspecies from rat brain: its structure, expression, and properties. Proc Natl Acad Sci USA 1989:86:3099-3103.

36. Coleman JB, Condie LW, Lamb RG. The role of $\mathrm{CCl}_{4}$ biotransformation in the activation of hepatocyte phospholipase $C$ in vivo and in vitro. Toxicol Appl Pharmacol 1988;95:208-219.

37. Storz $\mathrm{P}$, Doppler $\mathrm{H}$, Toker $\mathrm{A}$. Protein kinase $\mathrm{C}$ delta selectively regulates protein kinase D-dependent activation of NF-kappaB in oxidative stress signaling. Mol Cell Biol 2004;24:2614-2626. 
38. Brach MA, Gruss $\mathrm{HJ}$, Kaisho $\mathrm{T}$, et al. Ionizing radiation induces expression of interleukin 6 by human fibroblasts involving activation of nuclear factor-kappa B. J Biol Chem 1993;268:8466-8472

39. Pelletier C, Varin-Blank N, Rivera J, et al. Fc epsilon Rl-mediated induction of TNF-alpha gene expression in the RBL-2H3 mast cell line: regulation by a novel NF-kappaB-like nuclear binding complex. J Immunol 1998;161:4768-4776.

40. Luster MI, Simeonova PP, Gallucci RM, et al. Immunotoxicology: role of inflammation in chemical-induced hepatotoxicity. Int J Immunopharmacol 2000;22:1143-1147.

41. Morio LA, Chiu H, Sprowles KA, et al. Distinct roles of tumor necrosis factor-alpha and nitric oxide in acute liver injury induced by carbon tetrachloride in mice. Toxicol Appl Pharmacol 2001;172:44-51.

42. Louis $\mathrm{H}$, Van Laethem $\mathrm{JL}, \mathrm{Wu}$ W, et al. Interleukin-10 controls neutrophilic infiltration, hepatocyte proliferation, and liver fibrosis induced by carbon tetrachloride in mice. Hepatology 1998;28:1607-1615.

43. Thompson K, Maltby J, Fallowfield J, et al. Interleukin-10 expression and function in experimental murine liver inflammation and fibrosis. Hepatology 1998;28:1597-1606.

44. Rajasingh J, Bord E, Luedemann C, et al. IL-10-induced TNF-alpha mRNA destabilization is mediated via IL-10 suppression of p38 MAP kinase activation and inhibition of HuR expression. FASEB J 2006:20:2112-2114.

45. Bang OS, Park JH, Kang SS. Activation of PKC but not of ERK is required for vitamin E-succinate-induced apoptosis of HL-60 cells. Biochem Biophys Res Commun 2001;288:789-797.

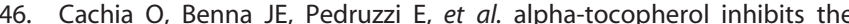
respiratory burst in human monocytes. Attenuation of p47(phox) membrane translocation and phosphorylation. J Biol Chem 1998, 273:32801-32805.

47. Ron D, Kazanietz MG. New insights into the regulation of protein kinase C and novel phorbol ester receptors. FASEB J 1999;13: 1658-1676.

48. Martinez-Hernandez A. The hepatic extracellular matrix. II. Electron immunohistochemical studies in rats with $\mathrm{CCl}_{4}$-induced cirrhosis. Lab Invest 1985;53:166-186.

49. Yang Jl, Yoon JH, Bang YJ, et al. Synergistic antifibrotic efficacy of statin and protein kinase $\mathrm{C}$ inhibitor in hepatic fibrosis. Am J Physiol Gastrointest Liver Physiol 2010;298:G126-G132.

50. Wasser S, Lim GY, Ong CN, et al. Anti-oxidant ebselen causes the resolution of experimentally induced hepatic fibrosis in rats. J Gastroenterol Hepatol 2001;16:1244-1253.

51. Kambayashi Y, Takekoshi S, Watanabe K, et al. Phospholipase C-dependent hydrolysis of phosphatidylcholine hydroperoxides to diacylglycerol hydroperoxides and its reduction by phospholipid hydroperoxide glutathione peroxidase. Redox Rep 2002;7:29-33.

52. Wenk J, Schuller J, Hinrichs C, et al. Overexpression of phospholipidhydroperoxide glutathione peroxidase in human dermal fibroblasts abrogates UVA irradiation-induced expression of interstitial collagenase/matrix metalloproteinase- 1 by suppression of phosphatidylcholine hydroperoxide-mediated NFkappaB activation and interleukin-6 release. J Biol Chem 2004;279:45634-45642.

53. Tsubota A, Yoshikawa $\mathrm{T}$, Nariai $\mathrm{K}$, et al. Bovine lactoferrin potently inhibits liver mitochondrial $8-\mathrm{OHdG}$ levels and retrieves hepatic OGG1 activities in Long-Evans Cinnamon rats. J Hepatol 2008; 48:486-493. 